\title{
Effect of inorganic compound on artificial stones' properties
}

\author{
Nasim Sarami ${ }^{1} \cdot$ Leila Mahdavian $^{1}$
}

Received: 10 February 2015/ Accepted: 2 July 2015/Published online: 15 July 2015

(c) The Author(s) 2015. This article is published with open access at Springerlink.com

\begin{abstract}
Many natural mines of decorative stones have been seen in the mountainous areas of the province Lorestan (Iran). Due to the traditional harvesting methods, these processes cause irreparable environmental damages. The formulation of decorative stone consists of travertine stone (TS) and marmarit stone (MS) with stone seeds 8-200 and 10-200. Cement, water, unsaturated polyester resin and fillers are used in the production of artificial stone composites from lesions of stone factory. The mechanical properties of TS with grain of size 10-200 are better than other grains and stones. The compressive strength of the samples was increased by reducing water content to $25 \%$ and increase of unsaturated polyester resin percentage to $12 \%$. To improve the properties of the samples and minimization of their pores, we used fillers such as calcium carbonate, silica, silane, titanium dioxide and zinc oxide. Calcium carbonate causes softening and loss of the composite samples. The results showed that use of the fillers including micro-silica, silane and titanium dioxide increases mechanical properties and eliminated close to all pores significantly. Unlike the concrete, artificial stone composite obtained in the absence of water pool showed better properties that increase with time.
\end{abstract}

Keywords Artificial stone $\cdot$ Lesions $\cdot \mathrm{TiO}_{2} \cdot \mathrm{ZnO}$. Mechanical parameters

Leila Mahdavian

Mahdavian_leila@yahoo.com; Mahdavian@iau-

doroud.ac.ir

1 Department of Chemistry, Doroud Branch, Islamic Azad University, P.O. Box: 133, Doroud, Iran

\section{Introduction}

Lorestan province due to natural minerals and 450 factories of decorative stone in Iran is considered one of the poles in this industry. Unfortunately, the $60 \%$ of mining stone has become lesions of stone factory (LSF) because the applied method is traditional. This problem is one of the considerable environmental issues in suburban of this province (Fig. 1).

The seasonal precipitation in these industrial cities is acidic which causes the dissolution of heavy metals of these lesions infiltrating them to groundwater, agricultural land that lead to bioaccumulation in food chain [1-3]. Despite these damages in suburban area, destruction of many plant species in these areas causes soil degradation.

In addition to the environmental risks of these lesions, another reason for recycling them is the loss of mineral resources $[4,5]$. The aim of this study is to find a method for removal and recycling of mentioned lesions, for instance artificial stone production.

The lesions as seen in Fig. 1 include unusable broken stones that are (with the dimensions of less than $10 \mathrm{~cm} \times 10 \mathrm{~cm}$ ) wastes of cutting of mining stone and sludge produced from cutting and polishing the stone.

Type of stone, composition and their chemical properties are important factors in the recycling. Lesions mainly include travertine and marmarit stone with the following properties:

- Travertine stone is a sedimentary limestone and porous calcite layer that is pretty crystalized and Travertine is a natural stone such as Marble, Granite, Onyx, Limestone, Slate and so on. The key difference between Travertine and other natural stones lies in the formation of the rock, the hardness of the stone and the 

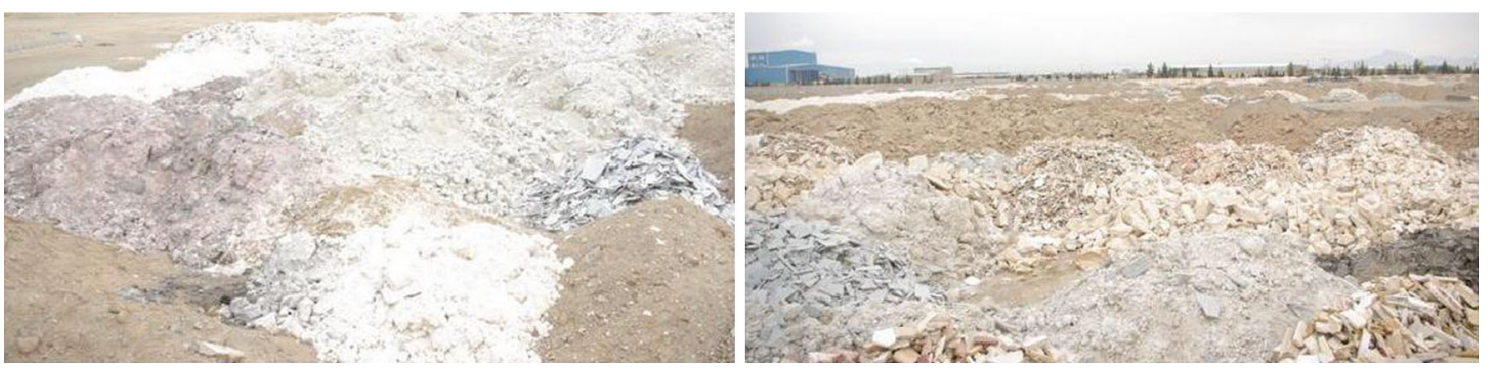

Fig. 1 The lesions of stone factory in and around Doroud city

appearance. Travertine is formed in hot springs and/or limestone caves [6, 7].

- Marmarit or Gohari stone is metamorphosed limestone under high pressure and heat conditions. In these metamorphic crystals, tiny crystals are re-crystallized toward coarser kinds. There are some veins in the marmarit including impurities in the original limestone [8].

The artificial stone of lesions in stone factory is produced by different formulations. Presence and absence of water pool, compressive strength and flexural tests are the factors that are measured in produced samples. To improve the properties of the produced artificial stone, fillers such as titanium dioxide $\left(\mathrm{TiO}_{2}\right)$ and zinc oxide $(\mathrm{ZnO})$ are added or mixed separately.

$\mathrm{TiO}_{2}$ as photo-catalyst is most widely used in different ways, in water treatment, air purifier, lubricants, anti-bacterial disinfectant, food industry, paint industry, paper manufacturing, oil and construction materials [9-11].

Titanium dioxide $\left(\mathrm{TiO}_{2}\right)$ has three different crystalline structures consisting of Anatase, Rutile and Brokit. Anatase makes the stone surface beautiful. For its self-cleaning behavior, $\mathrm{TiO}_{2}$ is used in building materials and structures [12-16] including cement mortars, exterior tiles, paving block, glasses, paints, finishing coating and concrete pavement. Zinc oxide $(\mathrm{ZnO})$ is a yellowish white powder and very soft with high specific surface area which improves the surface properties and other parameters of physical chemistry [17].

\section{Materials and devices}

$\mathrm{TiO}_{2}$ and $\mathrm{ZnO}$ are the products of MERK. Portland cement type II: This kind of cement has average properties, is means that setting time is low and is resistant to sulfate compounds, in this type of cement, amounts of tri-calcium silicate and di-calcium aluminates decreases and increases di-calcium silicate [18]. Other materials include: unsaturated polyester resins, micro-silica powder, $\mathrm{Si}$, lesions of stone factory are the products of MERK.
Required instruments in this study include press or kicker, mixer, water meter or meter setting (JOINT STARS GROUP LIMITED) and templates with sizes: $5 \times 5 \times 5$ and $16 \times 4 \times 4 \mathrm{~cm}^{3}$. Finally, sieves with mesh sizes 8,10 and 200 were used. The smaller the sample size, the larger is the mesh size.

- The size of drop meshes of sieve $200 \rightarrow$ $0.0075 \mathrm{~mm}=74$ micron $=0.0029$ in.

- The size of drop meshes of sieve $10 \rightarrow 2 \mathrm{~mm}=2000$ micron $=0.0787 \mathrm{in}$.

- The size of drop meshes of sieve $8 \rightarrow 2.38 \mathrm{~mm}=$ 2380 micron $=0.0937$ in.

Light microscope with Abbe condenser, N.A. of 1.25 and adjustable aperture (aperture center can be adjusted) was used. Electric components were: input voltage AC85-265 V, 50/60 Hz, output voltage DCI.2-6 V. $6 \mathrm{~V} /$ $20 \mathrm{~W}$ halogen lamp rotation potentiometer with power switch fuses $2 \mathrm{~A} 5 \times 20$ was used.

The compressive strength was evaluated using a product of Toni Technik Germany, device number PR41004 with the following specifications: serial number 1543-03, pressure $288 \mathrm{bar}$, piston stoke $60 \mathrm{~mm}$, diameter of piston $115 \mathrm{~mm}$, Toni Technik Gmbh-Gustav-Meyer-Allee 25, D-13355 Berlin.

The flexural strength was evaluated using a product from Toni Technik Germany RB421002 with the following characteristics: serial number 2061-03, pressure 125 bar, piston stroke $30 \mathrm{~mm}$, diameter of piston $32 \mathrm{~mm}$, Toni Technik Gmbh-Gustav-Meyer-Allee 25, D-13355 Berlin.

\section{Experimental methods}

For test of samples are used templates with sizes: $5 \times 5 \times 5$ and $16 \times 4 \times 4 \mathrm{~cm}^{3}$ and drop meshes of sieve size 10-200. According to formulation of Table 1, the composition of artificial stone base was determined. The amount of cement in artificial stone should be considered to stone seeds and the amount of other materials to be determined ratio to amount of cement. Notably, the mixes 
Table 1 The formulation of composition of artificial stone base

\begin{tabular}{ll}
\hline Material & Weight (\%) \\
\hline Stone & Same as mold \\
Cement & $20-70 \mathrm{wt} \%$ of stone \\
Resin polystyrene unsaturated & $1-10 \mathrm{wt} \%$ of cement \\
$\mathrm{H}_{2} \mathrm{O}$ & $20-30 \mathrm{wt} \%$ of Cement \\
Micro-Si or $\mathrm{CaCO}_{3}$ & $7 \mathrm{wt} \%$ of cement
\end{tabular}

or formulations of the samples are selected according to the ACI 211.1-91 Standard America [19].

\section{Methods of preparation of artificial stone}

Initially the cement is weighed and it was equivalent to $50 \%$ by weight of stone seeds, and water is $20-30 \mathrm{wt} \%$ of cement. Then water and cement were mixed into blender for $1 \mathrm{~min}$ at low rpm. After that we added stone seeds, unsaturated resin and filler $(7 \mathrm{wt} \%$ micro-Si or calcium carbonate for minimize pores) to mixture of water and cement and then mixed for $1.5 \mathrm{~min}$ at high $\mathrm{rpm}$. The mixture is ready for molding.

\section{The molding method of artificial stone}

After cleaning the templates, we installed them on kicker device. A layer of the mixture is poured into templates and the kicker machine is turned on, and 60 hits are to be imported. The second layer is poured and after 60 hits the mixture is set to air leak. Then, templates are kept in a humidity bath $\left(\theta=30^{\circ} \mathrm{C}\right.$ and $\omega=90 \%$ ) for 24 hours and are opened; the samples are put in the pool water at $20^{\circ} \mathrm{C}$ for different time periods $(3,7$ and 28 days). Unlike concrete, composite showed better resistance in absence of water as shown in Table 3.

\section{Compressive strength test}

The UK test according to standard BS EN 12390-1: 2000 and BS EN 12390-2: 2000 are performed [20]. After drying, the templates under compressive strength test are divided into two pieces for which $t_{1}$ and $t_{2}$ were the initial and final time, respectively, and compressive strength is calculated using the below formula:
$P(\mathrm{kN})=\frac{t_{1}-t_{2}}{2} \times 6.37$

Unit of compressive strength is $\mathrm{kN}$ and for conversion of $\mathrm{kN}$ to $\mathrm{kg} \mathrm{cm}^{-2}$, units are multiplied by a constant 6.37 .

\section{Flexural strength test}

The tensile strength test and applied axial tension were taken for the samples. Due to the shape of templates, there is a problem with the force being exerted in line with the axis. The tensile strength is calculated by indirect methods using the bending test and the splitting (split-half); it is according to standard BS EN 12390-5: 2000, and was conducted using the flexural strength[21, 22].

\section{Results and discussions}

At first, the samples were prepared by basic formulation: $450 \mathrm{~g}$ lesion of travertine stone with $10-200$ and 8-200 mesh of stone seeds, $50 \mathrm{wt} \%$ of cement, $1.5 \mathrm{wt} \%$ of resin and $30 \mathrm{wt} \%$. After $2-4 \mathrm{~h}$, the samples are transferred to water pool for $24 \mathrm{~h}$. The samples were porous and water absorption was high, so the samples did not show any resistance in compressive strength device (Table 2).

In the next sample, resin is increased up to $10-12 \mathrm{wt} \%$ and water is decreased to $20-25 \mathrm{wt} \%$ resulting in porosity decrease and increased compressive and flexural strength. The suburbs of samples are eaten and optical microscope does not show photograph, as related results are shown in Table 2. Table 3 shows the samples from lesions of TS and MS prepared in the presence and absence of water pool. The mechanical properties of dried samples in the absence of water pool are better. The TS stone seeds show less porosity and higher strength than the MS stone seeds. Flexural strength shows a significant increase in the absence of water for TS stone seeds.

To reduce the porosity of samples, cement is increased up to $70 \mathrm{wt} \%$ of stone seeds in TS and MS. The fillers (micro-Si and $\mathrm{CaCO}_{3}$ ) are added up to $5 \mathrm{wt} \%$ of cement. In Table 4 is shown their formulation and the samples were dried in the absence of water pool, samples containing

Table 2 The mechanical properties of artificial stone from stone lesions with 10-200 mesh in different combination

\begin{tabular}{|c|c|c|c|c|c|c|c|c|c|}
\hline \multirow{2}{*}{$\begin{array}{l}\text { Lesion of travertine stone (TS) } \\
\text { (g) }\end{array}$} & \multicolumn{2}{|l|}{ Cement (C) } & \multicolumn{2}{|l|}{ Water } & \multicolumn{2}{|c|}{$\begin{array}{l}\text { Resin of unsaturated } \\
\text { polystyrene }\end{array}$} & \multicolumn{2}{|c|}{$\begin{array}{l}\text { Compression } \\
\text { strength testing }\end{array}$} & \multirow{2}{*}{$\begin{array}{l}\text { Flexural strength testing } \\
\text { MP }\end{array}$} \\
\hline & $\mathrm{wt} \%$ to $\mathrm{TS}$ & $(\mathrm{g})$ & wt\% to $\mathrm{C}$ & (g) & wt $\%$ to $\mathrm{C}$ & (g) & $\mathrm{kN}$ & MP & \\
\hline 450 & 50 & 225 & 30 & 68 & 1.5 & 3.37 & 0 & 0 & 0 \\
\hline 450 & 50 & 225 & 25 & 56 & 10 & 22.5 & 6 & 2 & 0.45 \\
\hline 450 & 50 & 225 & 20 & 45 & 12 & 27.0 & 7 & 3 & 0.52 \\
\hline
\end{tabular}


Table 3 The mechanical properties of artificial stone from stone lesions with 10-200 mesh in the presence and absence of water

\begin{tabular}{|c|c|c|c|c|c|c|c|c|c|c|}
\hline \multirow[t]{2}{*}{ Kind of Stone } & \multirow{2}{*}{$\begin{array}{l}\text { Stone seed }(\mathrm{S}) \\
(\mathrm{g})\end{array}$} & \multicolumn{2}{|c|}{ Cement (C) } & \multicolumn{2}{|l|}{ Water } & \multicolumn{2}{|c|}{$\begin{array}{l}\text { Resin polystyrene } \\
\text { unsaturated }\end{array}$} & \multicolumn{2}{|c|}{$\begin{array}{l}\text { Compression } \\
\text { strength testing }\end{array}$} & \multirow{2}{*}{$\begin{array}{l}\text { Flexural strength testing } \\
\text { MP }\end{array}$} \\
\hline & & $\mathrm{wt} \%$ to $\mathrm{S}$ & (g) & $\mathrm{wt} \%$ to $\mathrm{C}$ & $(\mathrm{g})$ & wt\% to $\mathrm{C}$ & (g) & $\mathrm{kN}$ & MP & \\
\hline \multicolumn{11}{|c|}{ The presence of water for 3 days } \\
\hline $\mathrm{TS}$ & 900 & 50 & 450 & 25 & 112 & 12 & 54 & 2.98 & 0.88 & 0.23 \\
\hline MS & 900 & 50 & 450 & 25 & 112 & 12 & 54 & 0 & 0 & 0.25 \\
\hline \multicolumn{11}{|c|}{ The absence of water } \\
\hline TS & 900 & 50 & 450 & 25 & 112 & 12 & 54 & 6.17 & 3.80 & 0.67 \\
\hline MS & 900 & 50 & 450 & 25 & 112 & 12 & 54 & 4.53 & 2.50 & 0 \\
\hline
\end{tabular}

calcium carbonate (unlike concrete) were soft and disintegrated while the samples containing micro-Si were less porous and stronger than the formulation of Table 3.

According to the results in Table 4, the mechanical properties of this formulation are not satisfactory. The optical microscopy is a valuable method for examining the nature and progress of artificial stone and determines porosity and stone density. Figure 2 is optical microscopic images of samples with $7 \mathrm{wt} \%$ micro-Si for TS and MS. As is visible in Fig. 2, the dark areas show porosity in the artificial stone and the artificial stone of TS lesions is less porous.

In next step, micro-silica, $\mathrm{TiO}_{2}$ and $\mathrm{ZnO}$ are used as fillers in formulation. Table 5 includes the mechanical properties of these samples for which the filler content is $3 \mathrm{wt} \%$ of cement for $\mathrm{TiO}_{2}, \mathrm{ZnO}$ and a mixture of both. The samples containing titanium dioxide have a smoother and glossier surface than zinc oxide and a mixture of both; also the compressive strength of samples with $\mathrm{TiO}_{2}$ is better and their setting time is lower.

The samples made of a mixture of titanium dioxide and zinc oxide are better than zinc oxide, but all samples with formulation of Table 5 shows better mechanical properties with the passage of time. To increase of mechanical properties, we reduced $\mathrm{TiO}_{2}$ and $\mathrm{ZnO}$ fillers to $1 \mathrm{wt} \%$ of cement as well as increased micro-Si and silane to 7 and $1 \mathrm{wt} \%$ of cement, respectively. The results are shown in Table 6 . With the increase of micro$\mathrm{Si}$ and silane to formulations of artificial stone, the surfaces have been smoother and shinier than formulations of Table 5, the optical microscopic images of which are shown in Fig. 3.

As is visible in Fig. 3a, c, porosity of the samples containing titanium dioxide is less but the samples have smooth surface. The artificial stone of $\mathrm{TS}$ with $\mathrm{TiO}_{2}$ is denser because components of travertine stone formed a strong bond with the filler material $\left(\mathrm{TiO}_{2}\right)$ and is of low porosity. Chemical analyses of travertine stone waste of cutting factory to produce synthetic artificial stones are done for: $\mathrm{CaCO}_{3}, \mathrm{SiO}_{2}, \mathrm{FeS}_{2}, \mathrm{MgCO}_{3}$, clay $\left(\mathrm{Al}_{2} \mathrm{O}_{3}\right.$ and $\mathrm{Fe}_{2} \mathrm{O}_{3}$ ), sulfate and organic materials [23]. By comparing Figs. 2 and 3, it can be seen that fillers titanium dioxide and zinc oxide are better in forming crystalline structure and enhance the properties of artificial stone.

The mechanical properties of the samples containing $3 \mathrm{wt} \%$ of $\mathrm{TiO}_{2}$ or $\mathrm{ZnO}$ (Table 5) are more than $1 \mathrm{wt} \%$ of them (Table 6). Comparing the Tables 5 and 6, the compressive and tensile strength increase with addition of these fillers.

Table 4 The mechanical properties of artificial stone from stone lesions with 10-200 mesh with 7 wt $\%$ of filler equal $14.7 \mathrm{~g}$

\begin{tabular}{|c|c|c|c|c|c|c|c|c|c|c|}
\hline \multirow[t]{2}{*}{ Kind of filler } & \multirow{2}{*}{$\begin{array}{l}\text { Stone seed }(\mathrm{S}) \\
(\mathrm{g})\end{array}$} & \multicolumn{2}{|c|}{ Cement (C) } & \multicolumn{2}{|l|}{ Water } & \multicolumn{2}{|c|}{$\begin{array}{l}\text { Resin polystyrene } \\
\text { unsaturated }\end{array}$} & \multicolumn{2}{|c|}{$\begin{array}{l}\text { Compression strength } \\
\text { testing }\end{array}$} & \multirow{2}{*}{$\begin{array}{l}\text { Flexural strength testing } \\
\text { MP }\end{array}$} \\
\hline & & $\mathrm{wt} \%$ to $\mathrm{S}$ & (g) & $\mathrm{wt} \%$ to $\mathrm{C}$ & (g) & $\mathrm{wt} \%$ to $\mathrm{C}$ & (g) & $\mathrm{kN}$ & MP & \\
\hline \multicolumn{11}{|c|}{ Travertine stone } \\
\hline Micro-Si & 300 & 70 & 210 & 25 & 52 & 12 & 25 & 23.00 & 9.15 & 2 \\
\hline $\mathrm{CaCO} 3$ & 300 & 70 & 210 & 25 & 52 & 12 & 25 & 0 & 0 & 0 \\
\hline \multicolumn{11}{|l|}{ Marmarit stone } \\
\hline Micro-Si & 300 & 70 & 210 & 25 & 52 & 12 & 25 & 19.00 & 7.5 & 1.60 \\
\hline $\mathrm{CaCO} 3$ & 300 & 70 & 210 & 25 & 52 & 12 & 25 & 0 & 0 & 0 \\
\hline
\end{tabular}


Fig. 2 The optical microscope images of the artificial stone with $7 \mathrm{wt} \%$ micro-Si

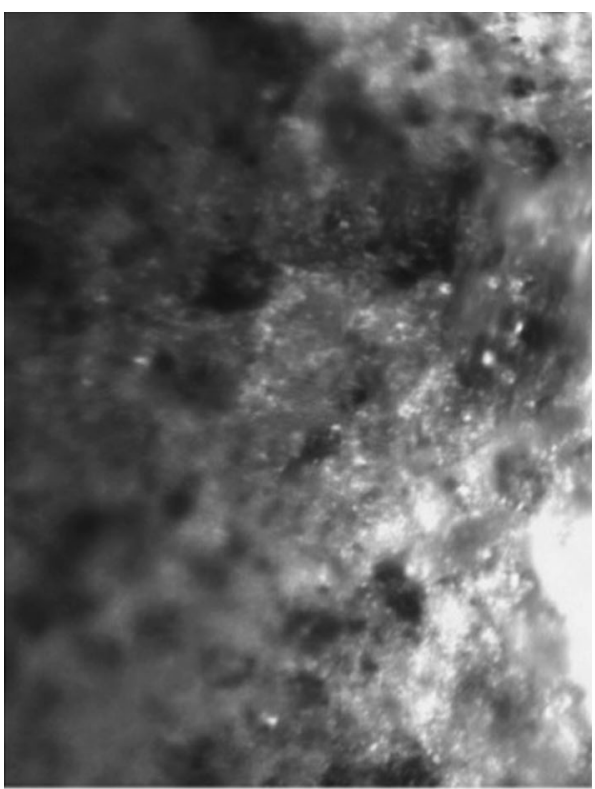

Travertine Stone

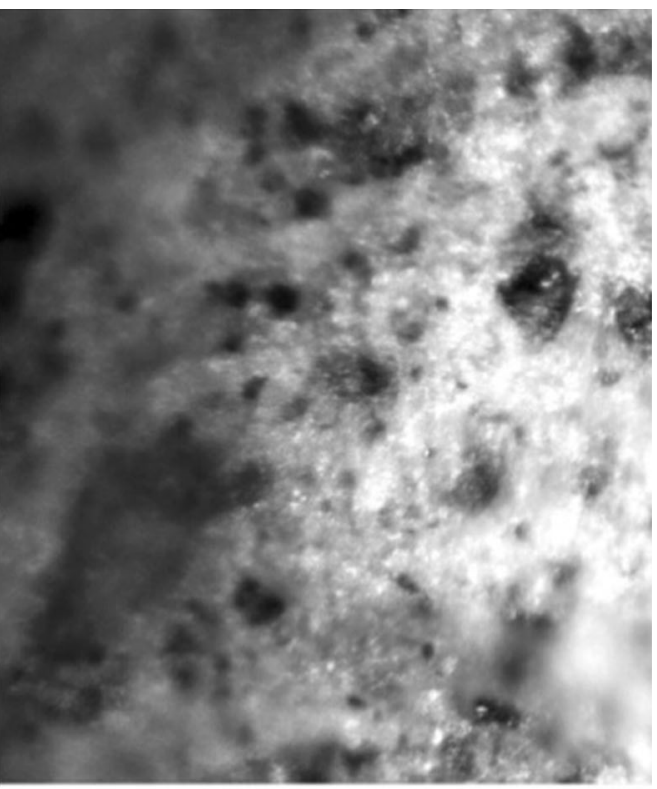

Marmarit Stone

Table 5 The mechanical properties of artificial stone from stone lesions of TS and MS with 10-200 mesh and $\mathrm{TiO}_{2}$ and $\mathrm{ZnO}$ fillers

\begin{tabular}{|c|c|c|c|c|c|c|c|c|c|c|}
\hline \multirow[t]{2}{*}{ Kind of filler } & \multirow{2}{*}{$\begin{array}{l}\text { Stone }(\mathrm{S}) \\
(\mathrm{g})\end{array}$} & \multicolumn{2}{|c|}{ Cement (C) } & \multicolumn{2}{|l|}{ Water } & \multicolumn{2}{|c|}{$\begin{array}{l}\text { Resin polystyrene } \\
\text { unsaturated }\end{array}$} & \multicolumn{2}{|c|}{$\begin{array}{l}\text { Compression strength } \\
\text { testing }\end{array}$} & \multirow[t]{2}{*}{ Flexural strength testing } \\
\hline & & wt $\%$ to $\mathrm{S}$ & $(\mathrm{g})$ & wt $\%$ to $\mathrm{C}$ & (g) & wt $\%$ to $\mathrm{C}$ & $(\mathrm{g})$ & $\mathrm{kN}$ & MP & \\
\hline \multicolumn{11}{|c|}{ The stone seeds of TS lesions with $3 \mathrm{wt} \%$ fillers equal $4.5 \mathrm{~g}$} \\
\hline $\mathrm{TiO}_{2}$ & 300 & 50 & 150 & 25 & 22 & 7 & 15 & 51.00 & 25.00 & 4.00 \\
\hline $\mathrm{ZnO}$ & 300 & 50 & 150 & 25 & 22 & 7 & 15 & 40.10 & 20.70 & 3.20 \\
\hline $\mathrm{TiO}_{2} \& \mathrm{ZnO}$ & 300 & 50 & 150 & 25 & 22 & 7 & 15 & 44.00 & 22.10 & 3.60 \\
\hline \multicolumn{11}{|c|}{ The stone seeds of MS lesions with $3 \mathrm{wt} \%$ fillers equal $4.5 \mathrm{~g}$} \\
\hline $\mathrm{TiO}_{2}$ & 300 & 50 & 150 & 25 & 22 & 7 & 15 & 30.43 & 13.00 & 2.32 \\
\hline $\mathrm{ZnO}$ & 300 & 50 & 150 & 25 & 22 & 7 & 15 & 21.01 & 8.36 & 1.00 \\
\hline $\mathrm{TiO}_{2} \& \mathrm{ZnO}$ & 300 & 50 & 150 & 25 & 22 & 7 & 15 & 22.50 & 9.00 & 1.12 \\
\hline
\end{tabular}

Table 6 The mechanical properties of artificial stone from stone lesions of TS with 10-200 mesh and $\mathrm{TiO}_{2}$, ZnO, micro-Si and silane fillers

\begin{tabular}{|c|c|c|c|c|c|c|c|c|c|}
\hline \multirow[t]{2}{*}{$\begin{array}{l}\text { Kind of } \\
\text { filler }\end{array}$} & \multirow{2}{*}{$\begin{array}{l}\text { Stone } \\
\text { (S) } \\
\text { (g) }\end{array}$} & Cement (C) & Water & $\begin{array}{l}\text { Resin } \\
\text { polystyrene } \\
\text { unsaturated }\end{array}$ & Micro-Si & Silane & \multicolumn{2}{|c|}{$\begin{array}{l}\text { Compression } \\
\text { strength } \\
\text { testing }\end{array}$} & \multirow{2}{*}{$\begin{array}{l}\text { Flexural strength } \\
\text { testing } \\
\text { MP }\end{array}$} \\
\hline & & $\begin{array}{l}\text { wt\% to (g) } \\
\text { TS }\end{array}$ & $\begin{array}{l}\mathrm{wt} \% \text { to (g) } \\
\mathrm{C}\end{array}$ & $\begin{array}{l}\mathrm{wt} \% \text { to (g) } \\
\mathrm{C}\end{array}$ & $\begin{array}{l}\mathrm{wt} \% \text { to } \quad(\mathrm{g}) \\
\mathrm{C}\end{array}$ & $\begin{array}{l}\mathrm{wt} \% \text { to }(\mathrm{g}) \\
\mathrm{C}\end{array}$ & $\mathrm{kN}$ & MP & \\
\hline
\end{tabular}

\begin{tabular}{|c|c|c|c|c|c|c|c|c|c|c|c|c|c|c|}
\hline \multicolumn{15}{|c|}{ The stone seeds of TS lesions with $1 \mathrm{wt} \%$ fillers $\left(\mathrm{TiO}_{2}\right.$ and $\left.\mathrm{ZnO}\right)$ equal $2.1 \mathrm{~g}$} \\
\hline $\mathrm{TiO}_{2}$ & 300 & 50 & 150 & 25 & 22 & 7 & 15 & 7 & 14.7 & 1 & 0.1 & 32.60 & 12.55 & 2.01 \\
\hline $\mathrm{ZnO}$ & 300 & 50 & 150 & 25 & 22 & 7 & 15 & 7 & 14.7 & 1 & 0.1 & 36.30 & 15.00 & 2.30 \\
\hline $\begin{array}{c}\mathrm{TiO}_{2} \& \\
\mathrm{ZnO}\end{array}$ & 300 & 50 & 150 & 25 & 22 & 7 & 15 & 7 & 14.7 & 1 & 0.1 & 25.00 & 10.00 & 1.70 \\
\hline
\end{tabular}




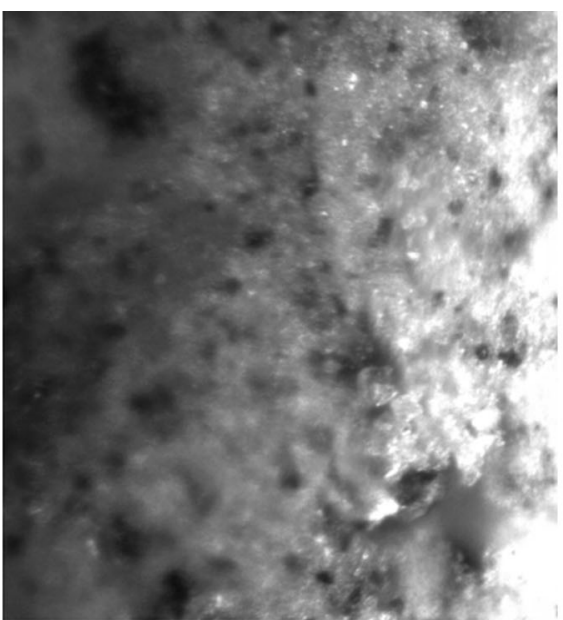

(a) $\mathrm{TiO}_{2}$

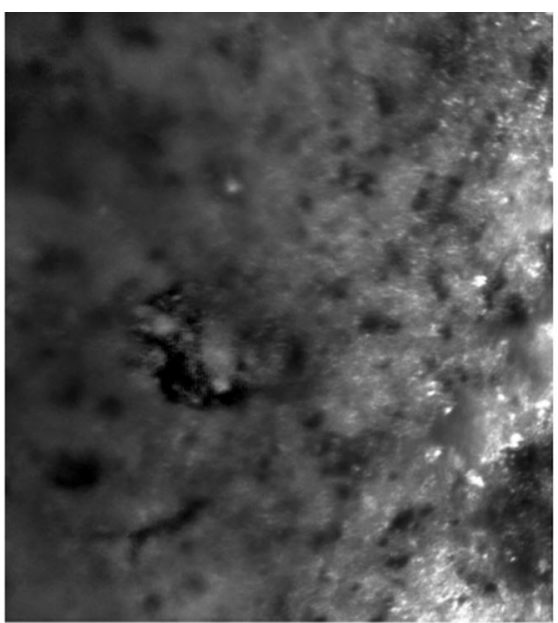

(b) $\mathrm{ZnO}$

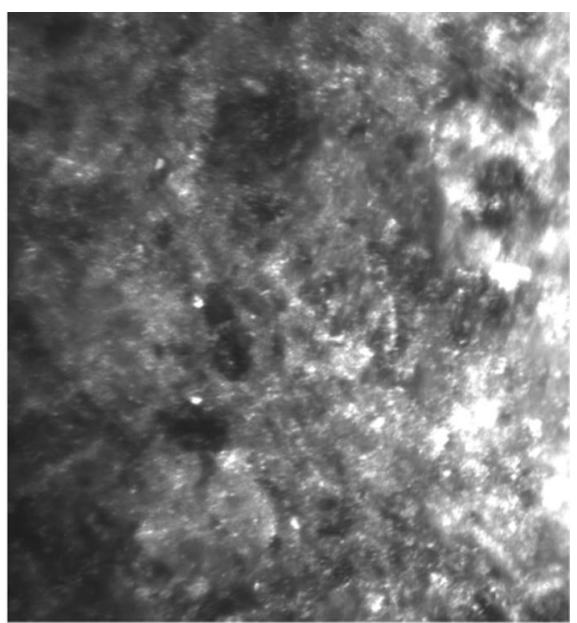

(c) $\mathrm{TiO}_{2} \& \mathrm{ZnO}$

Fig. 3 The optical microscope images of the artificial stone of TS lesions with fillers such as: micro-Si, silane and a $\mathrm{TiO}_{2}, \mathbf{b} \mathrm{ZnO}$ and $\mathbf{c}$ mixture of $\mathrm{TiO}_{2} \& \mathrm{ZnO}$

\section{Conclusion}

The aim of this study was conversion of stone factory lesions to artificial stones and recycling of these lesions. The results show mechanical properties of the prepared artificial stones with lesions of travertine stone (TS) are better than lesions of marmarit stone (MS). As a result, the percentage of TS lesions in waste of factories has direct relation with properties of produced artificial stones.

Unlike concrete, the compressive and tensile strength of artificial stone was better under exposure to air and without the presence of water pool and $\mathrm{CaCO}_{3}$ would be prepared to soften artificial stone. Titanium dioxide and zinc oxide as the fillers increased the mechanical properties and porosity of the samples. With increase of titanium dioxide, mechanical properties of artificial stone show a significant increase and these properties are increased with the passage of time.

Open Access This article is distributed under the terms of the Creative Commons Attribution 4.0 International License (http://crea tivecommons.org/licenses/by/4.0/), which permits unrestricted use, distribution, and reproduction in any medium, provided you give appropriate credit to the original author(s) and the source, provide a link to the Creative Commons license, and indicate if changes were made.

\section{References}

1. Wang JY, Touran A, Christoforou C, Fadlalla H (2004) A systems analysis tool for construction and demolition wastes management. Waste Manage 24(10):989-997

2. Kartam N, Al-Mutairi N, Al-Ghusain I, Al-Humoud J (2004) Environmental management of construction and demolition waste in Kuwait. Waste Manag 24(24):1049-1059
3. Bianchini G, Marrocchino E, Tassinari R, Vaccaro C (2005) Recycling of construction and demolition waste materials: a chemical-mineralogical appraisal. Waste Manage 25(2): 149-159

4. Azizian MF, Nelson PO, Thaymanavan P, Williamson KJ (2003) Environmental impact of highway construction and repair materials on surface and ground waters: case study: crumb rubber asphalt. Waste Manag 23(8):719-728

5. El-Gammal MI, Ibrahim MS, Badr EA, Asker SA, El-Galad NM (2011) Health risk assessment of marble dust at marble workshops. Nat Sci 9(11):144-154

6. Pentecost A (2005) Travertine. Kluwer Academic Publishers Group, The Netherlands. ISBN 1-4020-3523-3

7. Kanellopoulos C (2012) Distribution, lithotypes and mineralogical study of newly formed thermogenic travertines in Northern Euboea and Eastern Central Greece. Cent Eur J Geosci 4(4):545-560

8. Samani HY, Bafghi ARY (2012) Prediction of the sawing quality of Marmarit stones using the capability of artificial neural network. Int J Numer Anal Method Geomech 36(7):881-891

9. Enrico Q, Federica B, Giovanni BG, Caterina C (2012) Selfcleaning and de-polluting stone surface: $\mathrm{TiO} 2$ nanoparticles for limestone. Constr Build Mater 37:51-57

10. Lazar MA, Varghese S, Nair SS (2012) Photocatalytic water treatment by titanium dioxide: recent updates. Catalysts 2:572-601

11. Fujishma A, Zhang X, Tryk DA (2008) TiO2 photocatalysis and related surface phenomena. Surf Sci Rep 63:515-582

12. Chen J, Poon C (2009) Photocatalytic construction and building materials: from fundamentals to application. Build Environ 44:1899-1906

13. Benedix R, Dehn F, Quaas J, Orgass M (2000) Application of titanium dioxide photocatalysis to create self-cleaning building materials. Leipzig Annul Civil Engineering Report (LACER), vol 5. University of Leipzig, Leipzig, pp 157-168

14. Brunrlla MF, Diamanti MV, Pedeferri MP Di, Fonzo F, Casari CS, Bassi AL (2007) Photocatalytic behavior of different titanium dioxide layers. Thin Solid Films 515:6309-6313

15. Zhao X, Zhao Q, Yu J, Liu B (2008) Development of multifunctional photoactive self-cleaning glass. J Non-Cryst Solids 354:1424-1430 
16. Kawakami M, Furumura T, Tokoshige H (2007) NOx removal effects and physical properties of cement mortar incorporating titanium dioxide powder. In: Baglioni P, Cassar L, (eds), Proceedings of international RILEM symposium on photocatalysis. Environment and construction materials, 8-9 Oct 2007, Florence, Italy, Bagneux: Rilem, pp 163-70

17. Bondioli F, Ferrari AM (2009) Functionalization of ceramic tile surface by so-gel technique. J Colloid Interface Sci 334:195-201

18. Lea FM (1970) The chemistry of cement and concrete. Arnold, London

19. ACI Committee 211.1-91
20. Concrete Society (1976) Concrete core testing for strength, Technical Report. No. 11, p 44, London

21. ACI Committee 214.IR-81 (1984) Use of accelerated strength testing, Part 1: materials and properties of concrete, ACI Manual of Concrete Practice

22. BARBER PM (1933) Analysis of fresh concrete, concrete. (Discussion of recommendations for the assessment of the composition of fresh concrete) 17(6):12-13

23. Fahiminia M, Ardani R, Hashemi S, Alizadeh M (2013) Wastewater treatment of stone cutting industries by coagulation process. Arch Hyg Sci. 2(1):16-22 